\title{
Зөвлөлт, оросын монголч эрдэмтэн П. Балданжаповын монголын түүхийн сурвалж судлалд оруулсан хувь нэмэр (= О вкладе советского, российского ученого П. Б. Балданжапова в изучение монгольских исторических источников)
}

\section{Цолмон Содном ${ }^{1}$ Баярсайхан Даваасамбуу²}

\author{
1 Университет «Улан-Батор» (ул. Лувсанцэвээна, 5 квартал, 15 микрорайон, округ \\ Баянзурх, 13343 Улан-Батор, Монголия) \\ $\mathrm{Ph}$. D. (доктор исторических наук), профессор, проректор \\ iD 0000-0002-8903-018X. E-mail: tsolmon.sodnom@yahoo.com
}

2 Университет «Улан-Батор» (ул. Лувсанцэвээна, 5 квартал, 15 микрорайон, округ Баянзурх, 13343 Улан-Батор, Монголия)

$\mathrm{Ph}$. D. (доктор исторических наук), профессор

D 0000-0002-8898-6489. E-mail: bayraahistory@gmail.com

\author{
(C) КалмНЦ РАН, 2021 \\ (С) Цолмон С., Баярсайхан Д., 2021
}

\begin{abstract}
Аннотация. Введение. В 1958 г. Монгольской Академией наук была начата серия «Monumenta Historica», которая является основной базой более чем пятидесятилетних исследований современной исторической науки в Монголии. На создание этой серии оказало влияние несколько факторов. Во-первых, ведущие монгольские и зарубежные ученые провели огромную работу в Монголии и за рубежом и смогли собрать большой объем материала по монгольским источникам. Во-вторых, монгольско-советским коллективом ученых была издана «История Монголии», которая способствовала изучению методов исследования исторических источников. В-третьих, российскими и советскими учеными на тот период времени было опубликовано большое количество источников и научных работ, в числе которых следует назвать труды А. М. Позднеева, Ц. Ж. Жамцарано, Л. С. Пучковского, Н. П. Шастиной, С. Д. Дылыкова и других, внесших большой вклад в развитие источниковедческой науки; и отдельно отметим исследователя П. Б. Балданжапова. Цель исследования заключается в оценке вклада П. Б. Балданжапова в изучение монгольских исторических источников. Основными методами исследования послужили биографический, историко-проблемный и историко-описательный. Материалом для исследования были избраны основные источниковедческие работы П. Б. Балданджапова и обширный круг опубликованных источников по монгольской истории. Результаты. П. Б. Балданжапов исследовал основные источники по истории Монголии, такие как «Эрдэнийн Эрихэ» («Драгоценные четки») Галдана, «Цагаан түүх» («Белая история»), «Алтан Тобчи» («Золотое сказание») Мэр-
\end{abstract}




\section{Материалы IV Международного семинара «Письменное наследие \\ и актуальные проблемы истории и культуры монгольских народов», посвященного 100-летию со дня рождения Пурбо Балдановича Балданжапова}

гэн-гэгэна и др. Он превосходно владел монгольским письмом, прекрасно понимал содержание исходного памятника, в совершенстве владел источниковедческим анализом. П. Б. Балданжапов неоднократно посещал Монголию, им были скопированы многие источники, в том числе «Цагаан түүх» («Белая история») из собрания библиотеки монастыря Гандантегченлин. Bыводы. Тесная связь между П. Б. Балданжаповым и первым главным редактором серии «Monumenta Historica» Ш. Нацагдоржем еще со времен обучения в аспирантуре дает основание предполагать, что знание методологии исследований П. Б. Балданжапова и опубликованных им работ оказало большое влияние на методологию публикации всей серии «Monumenta Historica». Исследования монгольских источников, выполненные П. Б. Балданжаповым, не утратили своей научной значимости, они способствовали более глубокому изучению монгольской истории и письменной традиции и продолжают являться методологическим руководством для молодых монголоведов.

Ключевые слова: Пурбо Балданжапов, «Алтан тобчи», Галдан, история Монголии, исторические источники

Для цитирования: Цолмон С., Баярсайхан Д. Зөвлөлт, оросын монголч эрдэмтэн П. Балданжаповын монголын түүхийн сурвалж судлалд оруулсан хувь нэмэр (= О вкладе советского, российского ученого П. Б. Балданжапова в изучение монгольских исторических источников) // Монголоведение. 2021. Т. 13. №. 4. С. 672-684. (На монг.). DOI: $10.22162 / 2500-1523-2021-4-672-684$

\section{Purbo Baldanzhapov: The Soviet and Russian Scientist's Impact into the Research of Mongolian Historical Sources}

\section{Tsolmon Sodnom ${ }^{1}$, Bayarsayikhan Davaasambui ${ }^{2}$}

${ }^{1}$ Ulaanbaatar State University (5/15, Luvsantseveen St., Bayanzürkh District, 13343 Ulaanbaatar, Mongolia)

$\mathrm{Ph}$. D. (History), Professor, Vice Rector

iD 0000-0002-8903-018X. E-mail: tsolmon.sodnom@yahoo.com

2 Ulaanbaatar State University (5/15, Luvsantseveen St., Bayanzürkh District, 13343 Ulaanbaatar, Mongolia)

$\mathrm{Ph}$. D. (History), Professor

iD 0000-0002-8898-6489. E-mail: bayraahistory@gmail.com

(C) KalmSC RAS, 2021

(C) Tsolmon S., Bayarsaikhan D., 2021

Abstract. Introduction. In 1958, the Mongolian Academy of Sciences launched the "Monumenta Historica" series, which was to become the main venue of modern historical science in Mongolia for over fifty years of research in the field. Several factors were influential for the series reputation: $i$ ) leading Mongolian scholars, as well as scholars outside of Mongolia, worked hard in the country and abroad to collect a large amount of material on Mongolian sources; ii) the Mongolian-Soviet team of scholars published "History of Mongolia", which contributed to the study of research methods of historical sources; and iii) a large number of sources and scholarly works were published by Russian and Soviet scholars at the time, including such authors as A. M. Pozdneev, Ts. Zh. Zhamtsarano, L. S. Puchkovsky, N. P. Shastina, S. D. Dylykov, etc. whose contribution to the development of the source studies was invaluable. Among these scholars, we would like to single out Purbo B. Baldanzhapov. 


\section{Монголоведение • Mongolian Studies • 2021 • T. 13 • № 4}

The present article aims to describe Baldanzhapov's contribution to the study of Mongolian historical sources. Materials and methods. The main research methods employed for the study were biographical, historical-problematic, and historical-descriptive. Baldanzhapov's major publications in the field and a wide range of published sources on Mongolian history were the materials selected for the undertaken research. Results. The scholar's studies were focused on the main sources on the history of Mongolia, such as Galdan's "Erdeniin Erikhe" (Precious Rosary), "Tsagaan tukhe" (White History), "Altan Tobchi” (Golden History) by Mergen-gegen, etc. He had an excellent command of Mongolian script, perfectly understood the content of the original monuments, and was a master of the source analysis. Baldanzhapov made several visits to Mongolia and during his stays copied many sources, including "Tsagaan tukhe" from the collection in the library of the Gandantegchenlin monastery. Conclusions. Granted a close friendly relationship between Baldanzhapov and the first editor-in-chief of the "Monumenta Historica", Sh. Natsagdorj, who knew each other since their postgraduate days in Moscow, it may be assumed that the latter's knowledge of his friend's research methodology, as well as of Baldanzhapov's published works had an overall influence on the methodology of publications in the series. Baldanzhapov's studies of Mongolian sources have not lost their relevance, his elaborate contributions to Mongolian history and written tradition studies have served as a methodological guide for young Mongolian scholars.

Keywords: Purbo Baldanzhapov, 'Altan tobchi', Galdan, history of Mongolia, historical sources

For citation: Tsolmon S., Bayarsaikhan D. Purbo Baldanzhapov: The Soviet and Russian Scientist's Impact into the Research of Mongolian Historical Sources. Mongolian Studies (Elista). 2021; 13(4): 672-684. (In Mong.). DOI: 10.22162/2500-1523-2021-4-672-684

\section{Оршил}

Монголчууд түүхээ бичих, хуулбарлан олшруулж тараах нь эрт үеэс эхтэй боловч үндсэн эх сурвалжуудыг эрэн хайх, шинжлэх ухааны үүднээс судлан, хэвлэн нийтлэх, орчуулах нь 1921 онд Монгол улсад Судар бичгийн хүрээлэн анх байгуулагдсан цагаас эхлэн үе шаттай хийж эхэлсэн бөгөөд энэ жил Судар бичгийн хүрээлэн байгуулагдсны 100 жилийн ой тохиож буй юм.

Судар бичгийн хүрээлэнгийн эрдэмтэн судлаачид анх байгуулагдсан цагаас эхлэн монгол нутгаас ховор хуучин түүхийн ном судар хайж олох, солилцоо хийх, Монголын түүхийн гадаад хэл дээрх сурвалжуудыг орчуулах, энэ чиглэлээр гадаадын улс орнуудын эрдэмтэн мэргэдтэй харилцаа холбоо тогтоох, тэдэнд судлан шинжлэх боломжийг олгож, хамтын судалгааг хийхийг эрмэлзэж эхэлсэн билээ. Энэхүү ажилд Орос, Зөвлөлтийн эрдэмтдийн хамтын ажиллагаа, оролцоо чухал үр дүнтэй байсан билээ.

Түүхийн судалгааны ажлын гол материаллаг бааз болох нэгэнт цугларсан сурвалж бичгүүдийг, судлах, нийтлүүлэх ажлыг 1950-иад оны сүүлч, 60-аад оны эхнээс эхэлжээ.

Мөн энэхүҮ ажилд Орос, Зөвлөлтийн эрдэмтэд тухайлбал А. М. Позднеев [Позднеев 1883], Ц. Ж. Жамцарано [Жамцарано 1936], Л. С. Пучковский [Пучковский 1953], Н. П. Шастина [Шастина 1957], С. Д. Дылыков [Дылыков 1981], П. Б. Балданжапов [Балданжапов 1959: 163-170; Балданжапов 1970; Балданжапов, Ванчикова 2001; Балданжапов, Ванчикова 2012] нарын зэрэг эрдэмтэд эх бичиг, сурвалж судлалын талаар ном бүтээлүүд хэвлэж, эрдмийн зэрэг хамгаалж байсан нь монгол улсад монголын түүх бичлэг, сурвалж судлалын ухаан хөгжихөд чухал нөлөө үзүүлсэн билээ. Бид тэдгээрээс 


\section{Материалы IV Международного семинара «Письменное наследие \\ и актуальные проблемы истории и культуры монгольских народов», посвященного 100-летию со дня рождения Пурбо Балдановича Балданжапова}

монголын түүхийн гол томоохон сурвалжуудыг сонгон судалгаа хийж орос хэлнээ орчуулан судалгааны эргэлтэд оруулж, монгол төдийгүй олон улсын монгол судлаачдын анхаарлын төвд хүргэсэн П. Б. Балданжаповын судалгааны тухай энэхүҮ өгүүлэлдээ өгүүлэх болно.

1952-1954 онд Шинжлэх Ухааны Хүрээлэнгийн эрдэм шинжилгээний ажилтан Ш. Нацагдорж ЗХУ-ын Шинжлэх ухааны академийн Дорно дахины хүрээлэнгийн аспирантурт суралцаж байх тэр үеэс П. Б. Балданжаповтай танилцжээ. Ялангуяа П. Б. Балданжапов монголын түүхийн чухал нэгэн сурвалж болох Галдан туслагчийн «Эрдэнийн эрих» зохиолыг эрдмийн зэрэг хамгаалах сэдэв болгон сонгон авч олон эх, хувилбар, хуулбаруудыг харьцуулан үзэж, эрдэм шинжилгээний тайлбар хийх зэрэг сурвалж судлалын судалгаа хийж байсан нь Ш. Нацагдоржийн анхаарлыг зүй ёсоор татсан юм. Тэд өөрсдийн эрдмийн зэрэг хамгаалах судалгааны ажлын талаар санал солилцож, цаашдын хамтын ажиллагааны талаар ярилцаж зөвлөлдөж байжээ. Мөн Ш. Нацагдорж П. Б. Балданжаповыг хэд хэдэн удаа монголд ирэхэд нь хүрээлэнгийн эрдэмтэн, судлаачдад судалгааных нь ажлын талаар яриулж, санал бодлоо солилцох, Гандантэгчинлэн хийдийн номын сан, УННС-д хадгалагдаж байсан сурвалж бичгүҮд, түүхийн зохиолуудтай танилцах боломж олгож байсан нь түүний судалгааг монголын судлаачдад мэдүүлэхэд үр нөлөөгөө үзүүлсэн билээ.

ЗХУ-д эрдэмтний зэрэг хамгаалсан Ш. Нацагдорж буцаж ирсний дараа ахмад эрдэмтдийн цуглуулсан түүхэн сурвалж бичгүүдийг судлах, улмаар хэвлүүлэх ажлын чухлыг түүхч, судлаачидтайгаа зөвлөн ярилцаж эхний ээлжинд түүхийн 10 сурвалж эх хэрэглэгдэхүүнийг сонгон судалгаа хийн, хэвлэхээр тогтжээ. Түүгээр зогсохгүй сурвалж бичгүүдийг тусгайлан хэвлэдэг «Monumenta Historica» хэмээх эрдэм шинжилгээний цуврал сэтгүүлийг 1959 оноос эхлэн буй болгож Ерөнхий редактораар нь Ш. Нацагдоржийг томилжээ.

Тэр үед монгол зөвлөлтийн эрдэмтэд хамтран анх удаа Монгол улсын түүхийг нэгэн ботиор бичиж хэвлүүлсэн үе байсан бөгөөд эх сурвалж материалын үнэ цэн, судалгааны арга зүйн ач холбогдлыг чухалчлах болсон үе байв.

XX зуунаас өмнөх үеийн Монголын түүхийн сурвалжийн судалгаанд өөрийн гэсэн тодорхой ул мөрийг үлдээн, сурвалжийг судлан шинжих, хэвлэн нийтлэх ажилд онцгой үүрэг гүйцэтгэсэн нэгэн бол Оросын эрдэмтэн П. Б. Балданжапов болно. Тэрээр Монголын түүхийн үнэ цэнэтэй сурвалжууд болох Урадын Мэргэн гэгээний «Алтан товч», Галдан туслагчийн «Эрдэнийн эрих», «Цагаан түүх» зохиолуудыг эх бичиг, сурвалж судлалын үүднээс судлан эрдэм шинжилгээний тайлбар сэлтийн хамт орос хэлнээ орчуулсан байдаг. Монголын сурвалж бичиг судлалд оруулсан түүний хувь нэмрийг өгүҮлэхийн тулд дээр дурдсан 3 гол судалгааных нь талаар дэлгэрүүлэн авч үзье.

\section{Галдан туслагчийн «Эрдэнийн эрих»-ийн судалгаа}

1841 онд халхын Түшээт хан аймгийн туслагч Галдан «Эрдэнийн эрих хэмээх түүх болой» хэмээх нэгэн иж түүхийн зохиол бичсэн нь бидний үед товч болон дэлгэрэнгүй эх, хуулбар, хувилбараар өнөө үед уламжлагдан ирсэн бөгөөд монголын түүхийн сурвалж бичгүүдээс нэлээн сайн судлагдаж олон удаа хэвлэгдсэн сурвалжийн тоонд зүй ёсоор орж байна. 
1953-1956 онд ШУА-ийн Дорно дахины хүрээлэнгийн аспирантурт суралцахдаа П. Б. Балданжапов Галдан туслагчийн «Эрдэнийн эрих»-ийг судалгааны сэдэв болгон авчээ [Балданжапов 1956]. Түүний өмнө монголч эрдэмтэн А. М. Позднеев Галдан туслагчийн «Эрдэнийн эрих»-ийн хоёр ч эхийг монгол орноор судалгааны ажлаар явж байхдаа олж авчран түүнийгээ судлан эрдмийн зэрэг хамгаалжээ. Тэрбээр 1636 оноос 1736 хүртэлх 100 жилийн доторхи Ар Монголын түүхийн холбогдолтой хэрэглэгдэхүүнийг орос хэлээр орчуулан дэлгэрэнгүй тайлбар хавсаргаж 1883 онд нийтэлсэн нь А. Позднеевын «Эрдэнийн эрих» гэж нэгэнт алдаршжээ.

П. Б. Балданжапов эрдмийн зэрэг хамгаалах ажлынхаа сэдвийг сонгохдоо «Эрдэнийн эрих»-ийн ОХУ-д хадгалагдаж байгаа нэлээд хэдэн хувилбаруудыг судалгаандаа нэмэн хамруулж, уг сурвалжийг орос хэлнээ гүйцээн орчуулах зорилго тавьжээ.

Тэрбээр ОХУ-ын Санкт-Петербургийн Их сургуулийн Дорно Дахины факультетийн номын сан, ОХУ-ын ШУА-ийн Дорно дахины хүрээлэнгийн номын сан, ОХУ-ын Буриадын монгол, түвэд, буддын судлалын хүрээлэнгийн номын санд хадгалагдаж байсан 7 эхүүдийг харьцуулан судалж тэдгээрийг «Анхны эх», «Дэлгэрэнгүй эх», «Товчилсон эх» хэмээн ангилсан байна. «Анхны эх»-эд Г-316, С-37 эхүүдийг оруулаад Галдан туслагчийн өөрөө бичсэн, А. М. Позднеевын авчирсан эх мөн хэмээн тодорхойлоод Г-316-г гол болгон бусад эхүҮдэд байгаа зөрүүг дугаарлан нөхснөөр нэгэн сонгомол эхийг бий болгожээ.

П. Б. Балданжапов олдсон эх, хуулбар, хувилбаруудыг нарийвчлан шинжилж зохиогчийн тухай, зохиогдсон оныг 1849 гэх зөрүүтэй санал байсныг төгсгөлийн үгийг нягталснаар няцааж 1841 болохыг тогтоосон ба түүхэн хүн, газрын нэр, хуучин нэр томьёо болон төвд, санскрит үгийн дэлгэрэнгүй тайлбар хийж 1956 онд эрдмийн зэргээ амжилттай хамгаалжээ. Түүний диссертаци 583 хуудас байсан нь уг сурвалжийг эх бичиг, түүх бичлэг, түүхэн хэл шинжлэл, түҮхэн сурвалж болох талаас нь нягт нямбай судалсан нөр их ажил байсныг харуулж байна. Уг диссертацийн эрдэм шинжилгээний ач холбогдол нь зарим эрдэмтэн судлаачдын «Эрднийн эрих» нь бие даасан түүхэн зохиол бус олон сурвалжаас таслан авсан эвлүүлэг төдий хэмээснийг няцааж тэр үеийн түүх бичлэгийн онцлогтой холбон тайлбарлаж «Эрднийн эрих» бол монголын түүх, соёл, түүхэн хэл шинжлэлийн чухал нэгэн сурвалж болохыг өөрийн судалгаагаар тодорхой гаргаж өгсөнд уг судалгааны эрдэм шинжилгээний ач холбогдол оршино.

Тэрээр судалгааныхаа үр дүнгээр 1959 онд «Монгольская летопись “Эрдэнийн эрихэ” и ее значение в монгольской историографии» хэмээх томоохон өгүүлэл бичжээ. [Балданжапов 1959: 163-170]. Тус өгүүлэлдээ «Эрдэнийн эрих» зохиолын эхүүд, судалсан байдал, агуулга, түүх бичлэгийн онцлог, тэр цагт зохиогдсон бусад түүхийн зохиолуудаас ялгарах байдал, зохиогчийн тухай, сурвалжид хэрэглэгдсэн эх хэрэглэгдэхүүн, уг сурвалж хэвлэгдсэн он цаг, зэргийг нь харьцуулан үр дүнг нь тодорхой бичсэн байна. Уг өгүҮлэлдээ «Эрднийн эрих» бол «Болор толь», «Болор эрих», «Сувд эрих» зэрэгтэй харьцуулахад Монголын түүхэнд холбогдох чухал эх сурвалж мөн хэмээн үзжээ. 


\section{Материалы IV Международного семинара «Письменное наследие \\ и актуальные проблемы истории и культуры монгольских народов», посвященного 100-летию со дня рождения Пурбо Балдановича Балданжапова}

Монгол улсад анх удаа ахмад түүхч Ц. Насанбалжир «Monumenta Historica» цувралын III ботид Галдан туслагчийн «Эрднийн эрих» сурвалжийг 1960 онд хэвлүүлсэн юм [Насанбалжир 1960].

Ц. Насанбалжир Монгол улсын Үндэсний номын санд хадгалагдаж байсан «Эрдэнийн эрих»-ийн 5 эхээс «Эрдэнийн эрих түүх болой» хэмээх 472 тал хуудастай эхийг үндсэн эхээр сонгон, монгол бичгээр гараар сийрүүлэн бичиж хэвлүүлжээ. Галдан туслагч хошууны тамгын газар, аймгийн чуулган даргын болон засаг ноёны туслагчийн албан тушаал хашиж явсан төрийн албан хаагч байв. Тэрээр «Эрдэнийн эрих» хэмээх түүхэн сурвалжаа бичихдээ Монголын түүхэн сурвалжууд, Их Хүрээний сайд, Улиастайн манж жанжин, Халхын аймаг хошуудын данс харааг ашигласан бөгөөд 1841 онд бичиж дуусгажээ. «Эрдэнийн эрих» нь Халхын нутагт зохиогдсон цөөн сурвалжийн нэг бөгөөд Халхад бурхны шашин дэлгэрсэн түүх болон Халхын улс төрийн түүхийг хамруулан бичжээ. Халхын 6 хошууны ноёдын уг залгамжийг товч өгүүлсэн төдийгүй хөрш зэргэлдээ улсуудын түүхийг мөн хамруулахыг зорьжээ.

А. М. Позднеев, П. Б. Балданжапов нарын «Эрднийн эрих»-ийн судалгааг сайн мэдэх «Monumenta Historica» цувралын ерөнхий редактор Ш. Нацагдорж тус цувралын гуравдугаарт «Эрднийн эрих»-ийг хэвлүүлсэн нь уг сурвалжийн судалгааны цар хүрээг өргөтгөх, гүнзгийрүүлэх зорилготой байсныг харж болно. Өөрөөр хэлбэл Монгол улсад хадгалагдаж байгаа «Эрднийн эрих»ийн эхүүдийг судалгааны эргэлтэд оруулж олон орны судлаачдын анхааралд хүргэхийг зорьсон гэж болно. Тэр үед ахмад түүхч Ц. Насанбалжир тэр үеийн монгол улсын хэвлэлийн хөгжлөөс шалтгаалж сурвалжийн эхийг зургаар хэвлэх боломжгүй, гараар төмөр дээр сийрүүлэн хуулж бичээд хэвлэсэн нь бас мэр сэр алдаа гарахад хүргэсэн юм. Түүнийг нь дагалт хуудсаар залруулга хийсэн хэмээн ярьж байсан билээ. Ц. Насанбалжир энэхүҮ эхийг хэвлэхэд, нэгэнт хэвлэгдсэн байсан А. М. Позднеевын эхийг нэлээд ашигласан ба харин арга зүйн хувьд ерөнхий редактор Ш. Нацагдорж П. Б. Балданжапов эрдэмтний судалсан байдлаас хэлж зөвлөж байсан хэмээн дурсан ярьж байсан билээ.

Доктор Ж. Гэрэлбадрах Галдан туслагчийн «Эрднийн эрих»-ээс 16841802 оны хоорондох Халхын түүхийн хэсгийг хуулан оруулсан 1888-1889 оны үед зохиогдсон «Энэ нэгэн дэвтэр амуй» [Гэрэлбадрах 2006], мөн Монгол улсын үндэсний номын санд хадгалагдаж буй «Эрднийн эрих хэмээх түүх болай» [Гэрэлбадрах 2010] хэмээх эхийг гэрэл зургаар татаж, эрдэм шинжилгээний удиртгал, латин галиг, хөрвүүлэг, тайлбарын хамт хэвлүүлсэн нь уг судалгааг гүнзгийрүүлэхэд чухал болсон юм. Ингэхдээ ч мөн П. Б. Балданжаповын судалгааг нягтлан үзэж түүний ололтой тал, мөн эргэлзсэн болон санал нийлэхгүй зүйлийг тодорхой дурдсан байдаг. Тэрбээр Оросын эрдэмтэн П. Б. Балданжапов Орост хадгалагдаж буй Галданы «Эрднийн эрих»-ийн эхүүдийг харьцуулан нарийн судалгаа хийсэн билээ хэмээжээ [Гэрэлбадрах 2015: 19].

Мөн 2006, 2015 онд «Монголын түүхэн сурвалж бичгийн цуврал» 30 ботид Ж. Гэрэлбадрах Галданы «Эрднийн эрих»-ийг өргөн олон нийтэд зориулан орчин цагийн монгол хэлнээ буулган зохих тайлбарын хамт хэвлүүлсэн [Гэрэлбадрах 2006; Гэрэлбадрах 2015]. 
2012 онд ШУА-ийн Түүхийн хүрээлэнгээс эрхлэн гаргадаг «Monumenta Historica» цувралын IX ботид П. Б. Балданжаповын Санкт-Петербургийн Дорно дахины хүрээлэнгийн гар бичмэлийн хүрээлэнд хадгалагдаж буй «Эрднийн эрих»-ийн анхны бүрэн орос орчуулгыг эрдэм шинжилгээний судалгаа, тайлбар, уг сурвалжийн эхийг гэрэл зургийн хамт хэвлэн нийтэлсэн юм. Энэ хэвлэл нь П. Б. Балданжаповын 1956 онд эрдмийн зэрэг хамгаалсан диссертаци байсан бөгөөд орос орчуулгаа хараахан бүрэн дуусгаж амжаагүй байсны улмаас хэвлэж амжаагүй байсан юм. Түүний охин Ц. П. Ванчикова орчуулгыг дуусган редакторласнаар тийнхүу хэвлэгдэх боломжтой болжээ. П. Б. Балданжаповын сурвалж бичгийн судалгааг олон эрдэмтэд өндрөөр үнэлдэг бөгөөд «Monumenta Historica» цувралын ерөнхий редактор академич С. Чулуун энэ удаагийн хэвлэлийн өмнөх үгтээ: «Уг сурвалж нь хэдийгээр Монгол хэлээр хэд хэдэн удаа нийтлэгдсэн боловч ийм нарийвчилсан судалгаатай, тайлбар сэлттэйгээр орос хэлнээ анх удаа бүрэн орчуулагдан хэвлэгдсэн бөгөөд энэхүҮ эх нь одоогоор олдоод байгаа бусад эхүүдтэй харьцуулан үзвэл цаг хугацааны хувьд арай эртнийх гэж үзэж болохоор байгаагаараа онцлогтой байсан юм. П. Б. Балданжаповын орчуулга эрдэм шинжилгээний үнэ цэнээ өчүүхэн ч алдаагүй бөгөөд 1883 онд А. М. Позднеевын орчуулж, хэвлүүлсэн «Эрднийн эрих»-ийн 3 бүлгээс өөр 2012 оныг хүртэл «Эрднийн эрих»-ийн орос хэлээр орчуулсан бүрэн орчуулга гараагүй байсан билээ» хэмээн өндрөөр үнэлсэн билээ. [Балданжапов, Ванчикова 2012: 9].

\section{Мэргэн гэгээний «Алтан товч»-ийн судалгаа}

Чингис хааны төрсөн дүү Хавт Хасарын шууд угсааны хүн болох, өмнөд монголын Улаанцавын чуулган Урад дунд гүний хошууны Ар хорчин угсааны Мэргэн гэгээн ламын хувилгаан Лувсандамбийжалцан бээр 1765 онд «Их монгол улсын үндсэн алтан товч тууж оршвой» хэмээх нэгэн түүхийн зохиол бичсэн байна.

ОХУ-ын Санкт-Петербургийн Их сургуулийн дорно дахины салбарын номын санд хадгалагдаж буй энэ эхийг 1883 онд А. М. Позднеев тухайн үеийн ap монголын нутгаас олж илрүүлсэн бөгөөд. Энэ эх нь «Yeke monggul ulus-un ündüsün Altan tobči orošibai» гэсэн нэртэй, нийт 54 нүүр, хуудас нь дугааргүй, 42a талыг 8 мөрөөр, 54a талыг 4 мөрөөр бичсэн бөгөөд бусад бүх тал нь 9 мөрөөр хар бэхээр бичсэн байжээ.

П. Б. Балданжапов Мэргэн гэгээний «Алтан товч»-ийг эх бичиг, сурвалж судлалын ҮҮднээс нягт нямбай судлаж «Altan tobci — монгольская летопись XVIII века» [Балданжапов 1970] хэмээх нэгэн сэдэвт зохиолыг бичиж 1970 онд хэвлүүлжээ. Энэхүү ном оршил, үндсэн гурван хэсгээс бүтнэ. П. Б. Балданжапов номынхоо судалгааны хэсэгт сурвалжийг хэн хаанаас олсон, хаана ямар хувилбар хадгалагдаж байгаа, тус сурвалжийг хэн зохиосон болон зохиогдсон он цаг, сурвалжийн нэрийн тухай, уг сурвалжийн бүтэц, хэвлэгдсэн байдлын тухай, «Алтан товч»-ийг бичихэд ашигласан сурвалжуудын тухай өөрийн судалгааны үр дүн, дэвшүүлж буй саналын талаар тодорхой өгүүлжээ.

П. Б. Балданжапов энэхүҮ сурвалжийн судалгаанд шууд болон шууд бус холбогдох олон орны нэрт түүхч эрдэмтдийн судалгааг нягталж, «Юань-ши», «Судрын чуулган», «Монголын нууц товчоо» болон XVII-XVIII зууны монгол 


\section{Материалы IV Международного семинара «Письменное наследие \\ и актуальные проблемы истории и культуры монгольских народов», посвященного 100-летию со дня рождения Пурбо Балдановича Балданжапова}

сударч түүхчдийн бичсэн «Эрдэнийн товч», «Шар тууж», «Асрагч нэртийн тууж», «Болор эрих», «Алтан хүрдэн мянган хигээст бичиг» зэрэг сурвалж төдийгүй, хятад, төвд сурвалжийн мэдээг Мэргэн гэгээний «Алтан товч»-ийн мэдээтэй харьцуулан тайлбар хийж «Алтан товч» нь түүхийн чухал нэгэн сурвалж болохыг тодорхойлсон юм.

Монгол улсын төв номын санд нэг эх байсан хэмээн П. Б. Балданжапов бичсэн байдаг авч тэрхүү эх одоо нэгэнт үгүй болжээ хэмээн манай судлаачид бичсээр ирэв [Бүрнээ 2015: 6]. Харин бид Монгол улсын Төв номын санд «Хаадын түүх Алтан товчоо» хэмээх нэгэн гар бичмэл сурвалжийг олж судалгаандаа хэрэглэсэн бөгөөд тэрхүү сурвалжийг харгуулан үзэхэд Мэргэн гэгээний «Алтан товч» мөн байсан болно. Монгол улсын Төв номын сангийн гар бичмэлийн санд хадгалагдаж буй тус зохиол нь агуулгын хувьд бусад эхүүдтэй тэр дундаа Д. Бүрнээгийн хэвлүүлэхдээ баримталсан эхүүдтэй тохирно. «Алтан товч» зохиол нийт 33 бүлэгтэй бичигдсэн байдаг бөгөөд эдгээр бүлгүүд бүгд бий. Нийт 61 нүүр, хуудас нь дугааргүй, нэг нүүрэнд 10 мөрөөр хар бэхээр бичсэн, тусгайлсан нүүр байхгүй, харин хожим тус номны гарчиг болгож «Хаадын түүх Алтан товчоо» нэртэй гар бичмэл байна. Энэ нэрийг хожим нэмж бичсэн нь мэдэгддэг [Баярсайхан 2021: 125-139].

П. Б. Балданжаповын судалгааны нэг чухал ач холбогдол бол тэрээр энэхүҮ номдоо Мэргэн гэгээний «Алтан товч»-ийн ОХУ-д хадгалагдаж буй ховор гар бичмэл эхийг гэрэл зургаар хуулбарлан хавсаргасан нь бусад судлаачдад энэхүҮ эхийг судлах боломж олгожээ. Мөн 1942 онд Чуулалт хаалгад хэвлэсэн «Алтан товч»-ийн эхийн Санкт-Петербургийн гар бичмэл эхээс зөрөөтэй хэсгүүдийг номдоо хавсаргасан нь энэхүҮ сурвалжийг эх бичгийн үүднээс судлахад чухал хэрэглэгдэхүүн болсон юм.

П. Б. Балданжаповын судалгааны нэг үнэтэй чухал хэсэг бол тус сурвалжийн монгол эхийн орос орчуулга болон 591 үгийн тайлбар юм.

Мэргэн гэгээний «Алтан товч»-ийг орчин цагийн монгол хэлнээ хөрвүүлж, эрдэм шинжилгээний удиртгал бичиж хэвлүүлсэн доктор Д. Бүрнээ: «П. Б. Балданжаповын “Алтан товч”-ийн орос орчуулга нь мэргэн гэгээний найруулгын өнгө аяс, монгол бичгийн хэлний онцлогийг зарим нэгэн газар эндүүрч ташаа буулгасныг эс тооцвол монгол бичгийн ижил бичлэгтэй, салаа утгатай үгсийн утгыг, хам сэдвээс нь ургуулан нарийн нямбай буулгасан» хэмээжээ [Бүрнээ 2015: 8].

П. Б. Балданжапов нь төвд, монгол бичгийг сайн мэдэхийн дээр түүхэн хэл шинжлэлийн судалгаа хийсэн хүний хувьд эх бичгийн харьцуулсан судалгааг нягт нямбай хийхийн дээр уг сурвалжид хийсэн эрдэм шинжилгээний тайлбарууд нь олон талаас нь нягталсан учир хожмын судлаачдын судалгаанд ашиглагдсаар байдаг.

П. Б. Балданжаповын намтарт залуу байхаасаа хээрийн шинжилгээний ажилд оролцон газрын нэр усыг асуун сурвалжилж түүх домогтой нь цуглуулан судлаж байсан нь хожим дээрх сурвалжуудын эрдэм шинжилгээний тайлбар хийхэд түүний судалгаа үнэ цэнэтэй, эрдэм шинжилгээний ач холбогдолоо алдахгүй байхад нөлөөлсөн нэг хүчин зүйл гэж үзэж болно.

Монгол улсад төрийн соёрхолт, шинжлэх ухааны доктор, сурвалж судлаач Ш. Чоймаа санаачлан түүхэн сурвалж бичгүүдийг «Монголын түүхэн сурвалж 


\section{Монголоведение • Mongolian Studies • $2021 \bullet$ T. 13 • № 4}

бичгүүд» нэрийн дор цувралаар монгол бичгээс крилл үсгээр хөрвүүлэн олон нийтэд зориулан 2006 онд 30 боть, 2015 онд 33 ботиор эрдэм шинжилгээний тайлбартайгаар хэвлүүлсэн билээ. Энэхүү цувралын 2006 онд хэвлэгдсэн 30 боть, 2015 оны 14-р ботид доктор, профессор Д. Бүрнээ оршил бичиж, тайлбар хавсралтын хамт хэвлүүлсэн билээ. Чингэхдээ тайлбарыг хийхдээ төвд, монгол, сурвалж бичгүүд, толь бичгийг ашиглахын зэрэгцээ эрдэмтэн П. Б. Балданжаповын хийсэн тайлбарын тодорхой хэсгийг оруулан авснаа дурдсан байдаг [Бүрнээ 2015: 16].

Монголын ШУА-ийн сурвалжлагч гишүүн, шинжлэх ухааны доктор Х. Пэрлээ 1970-аад оны дундуур Түүхийн хүрээлэнгийн Дундад зууны түүхийн салбарын залуу ажилтан А. Очир, Б. Дорж, Б. Даваасүрэн, С. Цолмон нарт сурвалж бичгийн судлал, эх сурвалжтай ажиллах дадлага олгох сургалтдаа П. Б. Балданжаповын Урадын Мэргэн гэгээний «Алтан товч»-ийг гарын авлага болгон ашиглаж сурвалжийн эх, хуулбар, хувилбарыг харьцуулан ялгаж сурах, сурвалжийн зохиогчийг олж тогтоохдоо өссөн орчин олж авсан боловсрол, түүний ертөнцийг үзэх үзэл, алба хашиж байсан эсэх, тухайн сурвалжийн он цагийг хэрхэн тогтоох, бичигдэх үеийн нийгмийн байдал, тухайн сурвалж нь эх, хуулбар, хувилбар алин болохыг эхүүдийг харьцуулснаар олж тогтоох, олон эхүүд байвал хамгийн бүрэн гэж үзсэн эхийг гол болгон бусад эхүүдээр нөхвөрлөн сонгомол эх буй болгох, тэдгээрийг тогтооход төгсгөлийн үг чухал болох зэргийг зааж сургаж байсан билээ. Тэр үед «Monumenta Historica»гийн нэлээд хэдэн дугаар хэвлэгдсэн байсан ч П. Б. Балданжаповын Мэргэн гэгээний «Алтан товч»-ийг гарын авлага сургалтын эх материал болгон сонгож авч байсан нь нэгд, уг сурвалжийн судалгаа арга зүйн хувьд илүҮ ойлгомжтой, эрдэм шинжилгээний боловсруулалт, тайлбар нь сурвалж бичигтэй хэрхэн ажиллах ёстойг бодитойгоор харуулсан, чамбай судалгаа байсан, хоёрт, Зөвлөлтийн эрдэмтдийн судалгаа онол, арга зүгээс суралцахыг эрдэм шинжилгээний ажилтан нарт сануулдаг байснаас гадна орос хэлний мэдлэгээ дээшлүүлэхэд нь тустай, гуравт, монголд хэвлэгдсэн сурвалжуудыг өөрсдөө олоод үзэх боломжтой зэргийг харгалзсан хэрэг. П. Б. Балданжаповын эрдмийн бүтээлээс суралцах нь бид хэдээр хязгаарлагдаагүй түүхийн судалгаа хийж, XVII-XVIII зууны түүхэн сурвалж бичгийг уншиж судалсан хэн бүхэн түүний судалгаатай танилцаж түүний судалгааны тухай бүтээлдээ дурдаж арга зүйгээс нь санаа авч, суралцсан гэхэд хэтийдэхгүй.

\section{«Арван буянт номын цагаан түҮХ»}

Монголын төр, эрх зүйн дурсгалт бичгийн судалгаа нь монгол судлалын хамгийн бага хөндөгдсөн агаад олон талын мэдлэг шаардсан салбар юм. Ийм дурсгалын нэг бол «Арван буянт номын Цагаан түүх» буюу бидний товчлон нэрлэдгээр «Цагаан түүх» болно.

«Цагаан түүх»-ийн эх бичгийн судалгааг П. Б. Балданжапов 1967 оноос эхэлсэн бөгөөд судалгаа хийх явцдаа тэрбээр тухайн үеийн шинжлэх ухаанд мэдэгдэж байсан бүх эхүүдийг ашигласан бөгөөд өдгөө хүртэл өвлөгдөж ирээгүй боловч түүхэнд мэр сэр дурсагдах төдий эхүүдийг хүртэл тооцолсон байна.

Бидний хүртэл уламжлагдан үлдсэн «Цагаан түүх»-ийн хамгийн эртний эх XVI зуунд бичигдсэн бол хамгийн сүүлийн эх нь XIX зуунд хамаарах ажээ. 


\section{Материалы IV Международного семинара «Письменное наследие \\ и актуальные проблемы истории и культуры монгольских народов», посвященного 100-летию со дня рождения Пурбо Балдановича Балданжапова}

Тэрбээр «Цагаан түүх»-ийн судалгаагаа хэвлэлд бэлдэхдээ Гандангийн нэг, Ленинградын гурав, Улаанбаатарын гурав, Хөх хотын нэг эх дээр тулгуурлан бүх зөрүүтэй хэсгийг нягтлан шинжилсэн байдаг. Энэ хүнд дурсгалыг сонгон ажилласнаар П. Б. Балданжапов эх бичгийн хэл шинжлэлийн шүүмжлэл, нэр томъёонысэргээн шинэчлэл, эртний бичиг, бичвэр судлалын арга барил, түүхийн бүтээлийн шинжилгээний ерөнхий зарчим зэрэг дорно дахины судлалын олон салбарын өргөн их мэдлэгтэй болохоо харуулахын хамт судлагдахууныхаа онцлогийг бүрэн хэмжээгээр гарган хууль эрх зүйн чиглэлийн эх сурвалжийн нийтлэг хийгээд онцлог шинж чанарыг тодорхойлж чадсан байна.

Эртний монголчуудын төр ёсны ойлголт, өвөрмөц нэр томьёо хэллэг бүхий сонгодог монгол бичгийн дурсгалыг орос хэлнээ орчуулах нь нөр их мэдлэг, хүч, чармайлт шаардсан ажил байсан бөгөөд П. Б. Балданжапов түүхэн хэл шинжлэл, эртний бичиг, бичвэр судлалын арга барил, эртний дорно дахины улсууд болон монголын төр ёсны түүх, шашны гүн ухаан, монгол, төвд хэлийг сайн мэдэж байсны хүчинд энэхүү нүсэр ажлыг хийж чаджээ. П. Б. Балданжапов энэхүу судалгааг хийснээрээ дорно дахины судлалын олон салбарын өргөн мэдлэгтэй болохоо харуулахын хамт судлагдахууныхаа онцлогийг бүрэн хэмжээгээр гарган «Цагаан түүх»-ийн хууль, эрх зүйн чиглэлийн эх сурвалжийн нийтлэг хийгээд онцлог шинж чанарыг тодорхойлж чадсан байна.

«Цагаан түүх»-ийн судалгаагаa П. Б. Балданжапов шинжлэх ухааны докторын зэрэг горилсон бүтээл болгон бэлдэж байсан боловч харамсалтай нь 1974 онд хүндээр өвчилсний улмаас энэ ажлаа дуусгаж чадаагүй байна. 2001 онд түүний охин Ц. П. Ванчикова түүний судалгааг гүйцээж, орчуулгыг нь нягтлан хэвлүүлжээ. Өдгөө Цагаан түүхийн 15 эхийг олж тогтоогоод байгаа юм байна [Балданжапов, Ванчикова 2001].

Түүний хийсэн сурвалж бичгийн судалгааны давуу тал нь П. Б. Балданжапов нь эрт, дундад сонгодог монгол хэл, төвд хэлийг сайн мэддэг, түүхэн хэл шинжлэлийн онол арга зүйг сайн мэддэг байсан нь сурвалжийн агуулгыг ухаж ойлгох, орчуулах, тайлбар хийхэд түүний давуу тал болсон юм. Тийм ч учраас түүний судалгааны эрдэм шинжилгээний үнэ цэнэ буураагүй хожмын судлаачид түүний судалгааг нягтлан үзэж,өөрсдийн олж илрүүлсэн эхтэй харьцуулахын дээр үүний хийсэн тайлбарын нэлээд хувийг өнөөдөр ч хэвлэхдээ ашигласаар байна.

\section{Дүгнэлт}

Дээр өгүүлсэнийг нэгтгэн авч үзвэл Зөвлөлт, Оросын нэрт монголч эрдэмтэн П. Б. Балданжапов бээр Монголын түүхийн судалгаа, тэр дундаа сурвалж бичгийн судлалд өөрийн гэсэн жим мөрийг гаргаж, судалгааны үнэ цэнэтэй бүтээлүүдийг туурвиж, сурвалж судлалын судалгаанд өөрийн бүтээлээрээ болон судалгааны арга зүйгээрээ томоохон хувь нэмрийг оруулжээ. Үүнийг хэд хэдэн зүйлээр тодотгож болох юм. Үүнд:

Нэгд, П. Б. Балданжапов нь монголын түүхийн гол гол сурвалжуудыг сонгон авч судлахдаа ОХУ-ын Дорно дахины хүрээлэнгийн номын сан болон ИМБТ-ийн гар бичмэлийн санд хадгалагдаж буй ховор эхүүдийг сурвалжлан олж судалгаандаа хавсарган гэрэл зургаар хэвлүүлсэн нь олон улсын монголч эрдэмтдэд сурвалж бичгийн судалгаа хийх нь боломжийг нээж өгсөн. 


\section{Монголоведение • Mongolian Studies • 2021 • T. 13 • № 4}

Хоёрт, Түүхэн сурвалжийн эхүүдийг харьцуулах, тухайн сурвалжийн хамрах хүрээг тогтоох, сурвалжийн хамрах хүрээг тухайн сурвалжид дурдагдаж буй түүхэн хүн, он цагийг тодруулах, төгсгөлийн үгийг нягтлахын чухлыг, зохиогчийг тодруулах болон түүний ертөнцийг үзэх үзэл ямар орчинд өссөн, боловсрол хашиж байсан албан тушаал зэргийг тодруулахад өөрийн судалгаагаараа хожмын судлаачдад бодитой нөлөө үзүүлсэн, бүтээл нь судалгааны эх хэрэглэгдэхүүн, аргазүйн гарын авлага болсноороо монголын түүхийн сурвалж бичгийн судлалд томоохон хувь нэмэр болсон гэж үзэж болно.

Гуравт, Тэрбээр хэвлүүлсэн сурвалжууддаа нягт нямбай, дэлгэрэнгүй эрдэм шинжилгээний тайлбар хийсэн нь сурвалж бичгийн судалгааг гүнзгийрүүлэх төдийгүй намтар судлал, газрын нэр судлалд ч чухал хувь нэмэр болж түүний тайлбар нь өдгөө ч эрдэм шинжилгээний ач холбогдлоо алдаагүй, сурвалж бичгийн судалгаанд ашиглагдсаар байна.

\section{Литература}

Балданжапов 1956 - Балданжапов П. Б. Монгольская летопись «Эрдэнийн эрихэ» как исторический источник: автореф. дисс. ... канд. ист. наук. М., 1956. 12 с.

Балданжапов 1959 - Балданжапов П. Б. Монгольская летопись «Эрдэнийн эрихэ» и ее значение в монгольской историографии // Монгольский сборник: экономика, история, археология. М.: Изд-во вост. лит, 1959. С. 163-170.

Балданжапов 1970 - Балданжапов П. Б. Altan tobči. Монгольская летопись XVIII в. Исследование, монгольский текст с разночтениями, перевод и комментарии. Улан-Удэ: Вост. лит., 1970. 415 с.

Балданжапов, Ванчикова 2001 - С̆aүan teüke - «Белая история» - монгольский историко-правовой памятник XIII-XVI вв. / сост. критического текста, перевод «Белой истории» П. Б. Балданжапова; исследование, редактирование перевода, составление комментариев, подготовка к публикации, перевод и комментарий к шастрам «Хана-чакравартина» и «Орунга» Ц. П. Ванчиковой. Улан-Удэ: БНЦ РАН, 2001. $200 \mathrm{c}$.

Балданжапов, Ванчикова 2012 - Галдан. История, именуемая “Эрдэнийн эрихэ”. Исследование и комментированный перевод на русский язык П. Б. Балданжапова, Ц. П. Ванчиковой. Monumenta Historica. Tom. X. Fasc. 1. Улан-Батор; Улан-Удэ: ADMON, 2012. $441 \mathrm{c}$.

Баярсайхан 2021 - Баярсайхан Д. Монголын түүх бичлэг (XVIII зуун). III боть. Улаанбатар: Соёмбо принтинг, 2021. 192 х.

Бүрнээ 2015 - Мэргэн гэгээн Лувсандамбижалиан. Их монгол улсын үндсэн алтан товч тууж оршивой / монгол бичгээс хөрвүүлэн, оршил, тайлбар, хавсралт хийсэн Д. Бүрнээ. Монголын түүхийн сурвалж бичиг. Боть 14. Улаанбаатар, 2015. 216 х.

Гэрэлбадрах 2006 - Ene nigen debter amui / transcription by J. Gerelbadrakh. Monumenta Historica Mongolorum. T. II. Ulaanbaatar: Mongolian State University of Education, 2006. 103 x.

Гэрэлбадрах 2010 - Галдан туслагч “Эрдэнийн эрих хэмээх түүх болой” / эрдэм шинжилгээний удиртгал, хөрвүүлэг, тайлбар бичсэн Дуутан Ж. Гэрэлбадрах. Улаанбаатар: Бемби сан, 2010. 222 х.

Гэрэлбадрах 2015 - Галдан туслагч “Эрдэнийн эрих хэмээх түүх болой” / эрдэм шинжилгээний удиртгал, хөрвүүлэг, тайлбар бичсэн Дуутан Ж. Гэрэлбадрах. Монголын түүхийн сурвалж бичгүүд. Боть 23. Улаанбаатар: Соёмбо принтинг, 2015. $346 \mathrm{x}$.

Дылыков 1981 - Их Цааз («Великое уложение»). Памятник монгольского феодального права XVII в. Ойратский текст / транслитерация сводного ойратского текста, 


\section{Материалы IV Международного семинара «Письменное наследие \\ и актуальные проблемы истории и культуры монгольских народов», посвященного 100-летию со дня рождения Пурбо Балдановича Балданжапова}

реконструированный монг. текст и его транслитерация, пер., введ. и коммент. С. Д. Дылыкова. М.: Наука, ГРВЛ, 1981. 147 с.

Жамцарано 1936 - Жамиарано Ц. Ж. Монгольские летописи XVII в. М.; Л.: Изд-во AH CCCP, 1936. 122 c.

Насанбалжир 1960 - Галдан. Эрдэнийн эрих хэмээх түүх болой / Ц. Насанбалжир хэвлэлд бэлтгэвэй. Monumenta Historica. Tom. III. Fasc. I. Улаанбаатар: ШУДБ Хүрээлэнгийн Эрдэм шинжилгээний хэвлэл, 1960. 166 х.

Позднеев 1883 - Позднеев А. М. Монгольская летопись “Эрдэнийн Эрихэ”: подлинный текст с переводом и пояснениями, заключающими в себе материалы для истории Халхи с 1633 по 1736 гг. СПб.: Тип. Имп. Акад. наук, 1883. 421 с.

Пучковский 1953 - Пучковский Л. С. Монгольская историография XIII-XVII вв. // Ученые записки Института востоковедения АН. Т. VI. М.; Л.: Изд-во АН СCCP, 1953. С. 131-166.

Пучковский 1957 - Пучковский Л. С. Монгольские, бурят-монгольские и ойратские рукописи и ксилографы Института востоковедения. История, право. Вып. 1. М.; Л.: Изд-во АН СССР, 1957. 280 с.

Шастина 1957 — «Шара туджи» — монгольская летопись XVII века / сводный текст, пер., введ. и примеч. Н. П. Шастиной, М.; Л.: Изд-во АН СССР, 1957. 199 с.

\section{References}

Altan Tobči: A $18^{\text {th }}$ Century Mongolian Chronicle. P. Baldanzhapov (study, transl., etc.). Ulan-Ude, 1970. 415 p. (In Russ.)

Baldanzhapov P. B. Erdeni-yin Erike and its significance for Mongolian historiography. In: Mongolian Collection. Economics, History, Archaeology. Moscow, 1959. Pp. 163-170. (In Russ.)

Baldanzhapov P. B. The Mongolian Manuscript Titled 'Erdeni-yin Erike' as a Historical Source. Cand. Sc. (history) thesis abstract. Moscow, 1956. (In Russ.)

Bayarsaikhan D. Mongolian Historical Sources, $18^{\text {th }}$ Century. Vol. III. Ulaanbaatar, 2021. 192 p. (In Mong.)

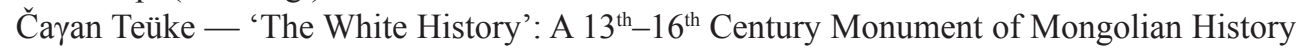
and Law. P. Baldanzhapov (comp., transl.); Ts. Vanchikova (study, ed., etc.). Ulan-Ude, 2001. 200 p. (In Russ.)

Ene Nigen Debter Amui. Ser. 'Monumenta Historica Mongolorum'. Vol. II. J. Gerelbadrakh (translit.). Ulaanbaatar, 2006. 103 p. (In Mong.)

Galdan. A History of Mongols Titled 'Erdeni-yin Erike'. P. Baldanzhapov, Ts. Vanchikova (study, transl.). Ser. 'Monumenta Historica'. Vol. X. Part 1. Ulaanbaatar; Ulan-Ude, 2012. 441 p. (In Russ.)

Galdan. The Chronicle Titled 'Erdeni-yin Erike'. J. Gerelbadrakh (translit., introd., etc.). Ulaanbaatar, 2010. 222 p. (In Mong.)

Galdan. The Chronicle Titled 'Erdeni-yin Erike'. J. Gerelbadrakh (translit., introd., etc.). Ser. 'Mongolian Historical Records'. Vol. 23. Ulaanbaatar, 2015. 346 p. (In Mong.)

Galdan. The Chronicle Titled 'Erdeni-yin Erike'. Ser. 'Monumenta Historica'. Vol. III. Part I. Ts. Nasanbaljir (text prep.). Ulaanbaatar, 1960. 166 p. (In Mong.)

Ikh Tsaaz ('The Great Code of Laws'): A $17^{\text {th }}$ Century Monument of Mongolian Feudal Law. Oirat text. S. Dylykov (translit., reconstr., etc.). Moscow: Nauka — GRVL, 1981. 147 p. (In Russ. and Oir.)

Jamtsarano Ts. J. $17^{\text {th }}$ Century Mongolian Manuscripts. Moscow, Leningrad: USSR Academy of Sciences, 1936. 122 p. (In Russ.)

Luvsandambijaltsan M. G. The Great Mongolian Chronicle Titled ‘Altan Tobči'. D. Bürnee (translit., introd., etc.). Ser. 'Mongolian Historical Records'. Vol. 14. Ulaanbaatar, 2015. 216 p. (In Mong.) 
Pozdneev A. M. The Mongolian Chronicle Titled 'Erdeni-yin Erike': Original Text Supplemented with a Russian Translation and Comments to Serve as Materials for the 1633-1736 History of Khalkha. St. Petersburg: Imperial Academy of Sciences, 1883. 421 p. (In Mong. and Russ.)

Puchkovsky L. S. Institute of Oriental Studies: Mongolian, Buryat Mongolian, and Oirat Manuscripts and Xylographs on History and Law. Vol. 1. Moscow, Leningrad: USSR Academy of Sciences, 1957. 280 p. (In Russ.)

Puchkovsky L. S. Mongolian historiography, $13^{\text {th }}-17^{\text {th }}$ centuries. In: Institute of Oriental Studies. Scholarly Notes. Vol. VI. Moscow, Leningrad: USSR Academy of Sciences, 1953. Pp. 131-166. (In Russ.)

Sira Turuči: A $17^{\text {th }}$ Century Mongolian Chronicle. N. Shastina (text, introd., etc.). Moscow, Leningrad: USSR Academy of Sciences, 1957. 199 p. (In Russ.) 